\title{
ANALISIS TIPE KEPEMIMPINAN PATERNALISTIK DALAM PENINGKATAN PELAYANAN PUBLIK DI TENGAH SITUASI PANDEMIK COVID-19
}

\author{
Siti Marwiyah', Nur Halima², Finni Maulidi ${ }^{3}$ \\ ${ }^{1}$ Fakultas Ilmu Sosial dan Ilmu Politik, Universitas Panca Marga Probolinggo \\ email: sitimarwiyah@upm.ac.id \\ ${ }^{2}$ Fakultas Ilmu Sosial dan Ilmu Politik, Universitas Panca Marga Probolinggo \\ Korespondensi email: nurhalima2346@gmail.com \\ ${ }^{3}$ Fakultas Ilmu Sosial dan Ilmu Politik, Universitas Panca Marga Probolinggo \\ email: maulidifinni@gmail.com
}

\begin{abstract}
Currently, the Covid-19 pandemics have begun to cause real loss among the public. Many victims who have attacked Indonesian society, began to the sick even to death. It is enough to make the community panic and fear the Covid-19 pandemics. So how can a leader make people calm and take care. The handling done to date is social distancing. However, various forms of public service are still run by government. As a leader with the type of the head of the community that is widely found in the environment, it is still traditional. In other words, his legitimacy of leadership is seen as natural and normal with its organizational implications, such as commanding authority and decision making without having to consult with his subordinates in prioritizing togetherness. Research was conducted to know how the type of paternalistic leadership in the village of Ketapang Kota Probolinggo increased the public service in the middle of the Covid-19 pandemics. With the results of the paternalistic leadership type research affects the level of public servants in the Covid-19 pandemic.
\end{abstract}

Keyword: covid-19 pandemic; public service; paternalistic leadership.

\begin{abstract}
ABSTRAK
Saat ini pandemik Covid-19 sudah mulai menyebabkan kerugian nyata di kalangan masyarakat. Banyaknya korban yang telah menyerang masyarakat Indonesia, mulai yang sakit bahkan sampai meninggal dunia. Hal tersebut cukup membuat masyarakat panik dan takut akan pandemik Covid-19. Maka bagaimana seorang pemimpin dapat membuat masyarakat dapat tenang dan melakukan penanganan. Penanganan yang dilakukan sampai saat ini adalah melakukan pembatasan sosial (social distancing). Namun berbagai bentuk pelayanan publik masih dijalankan oleh pemerintahan. Sebagai seorang pemimpin dengan tipe kepemimpinan peternalistik yang banyak terdapat di lingkungan masyarakat, yang masih bersifat tradisional. Dengan perkataan lain, legitimasi kepemimpinannya dipandang sebagai hal wajar dan normal dengan implikasi organisasional nya, seperti kewenangan memerintah dan mengambil keputusan tanpa harus konsultasi dengan para bawahannya dalam mengutamakan kebersamaan. Penelitian dilakukan untuk mengetahui bagaimana tipe kepemimpinan paternalistik di Kelurahan Ketapang Kota Probolinggo meningkatkan pelayanan publik di tengah pandemik Covid-19. Dengan hasil penelitian tipe kepemimpinan paternalistik mempengaruhi tingkat pelayan publik di masa pandemi Covid-19.
\end{abstract}

Kata Kunci: pandemi covid-19; pelayanan publik; kepemimpinan paternalistik. 


\section{PENDAHULUAN}

Pandemik Covid-19 mengancam jutaan nyawa. Dibandingkan dengan flu musiman, perkiraan saat ini menunjukkan bahwa virus Covid-19 baru hampir dua kali lebih menular, dan itu memakan waktu lebih 1 lagi untuk gejala sampai sekarang. Dengan demikian, seseorang yang merasa sehat mungkin tanpa sadar menularkan penyakit kepada orang lain sebelum mereka bahkan tahu mereka sakit. Pandemik Covid-19 hadiah krisis tumbuh kesehatan masyarakat, dan perkiraan terburuk saat ini, oleh Pusat Pengendalian dan Pencegahan Penyakit dan lain-lain, menunjukkan bahwa di mana saja antara $60 \%$ dan $80 \%$ dari orang mungkin akhirnya kontrak Covid-19, berpotensi membunuh puluhan jutaan (Everett et al., 2020).

Dalam lingkungan masyarakat, tentunya masyarakat menginginkan sebuah pemimpin yang bijaksana, efektif dan tanggung jawab. Masyarakat berharap agar pemimpin di daerahnya dapat menampung aspirasi atau ide-idenya dalam mengambil suatu keputusan. Terlebih lagi dalam sebuah masalah skala internasional yang cukup mengkhawatirkan, peran pemimpin sangat diperlukan.

Dalam setiap aspek kehidupan tentunya tidak terlepas dari sebuah pengaruh dan yang dipengaruhi. Sehingga tidak asing lagi yang terdengar istilah kepemimpinan. Pemimpin merupakan orang yang melaksanakan suatu organisasi, lembaga dan sebagainya. Sedangkan kepemimpinan adalah sifat yang dimiliki seorang pemimpin dalam melaksanakan suatu roda organisasi, lembaga dan yang lainnya. Kepemimpinan pada dasarnya sifat bawaan yang dimiliki pemimpin (Asy'ari et al., 2013).

Menurut Daswati (2012) kepemimpinan memiliki peranan sebagai suatu perilaku yang dilakukan oleh seorang pemimpin sesuai dengan kedudukannya sebagai bentuk harapan dari bawahannya. Di dalam organisasi sendiri mengidentifikasikan suatu pekerjaan yang dikerjakan dan perilaku peran yang diinginkan berjalan dengan seiring pekerjaan tersebut, sehingga harapan mengenai peran penting dalam mengatur perilaku bawahan (Hadiyanti, 2015).

Di dalam lingkungan masyarakat agraris ada banyak seorang pemimpin dengan tipe kepemimpinan paternalistik yang masih bersifat tradisional. Pemimpin dengan tipe kepemimpinan tersebut biasanya disebabkan oleh beberapa faktor misalnya adanya peranan adat istiadat yang sangat kuat di dalam lingkungan masyarakat, adanya kedekatan hubungan antara masyarakat yang satu dengan yang lain, adanya ikatan Primordial, dan extended family system. Fakto-faktor tersebutlah yang biasanya seorang pemimpin dengan tipe paternalistik cukup dekat dengan masyarakat maupun bawahannya di dalam sebuah organisasi (Erlangga et al., 2014).

Dalam kondisi tersebut bagaimana pemerintah dapat memberikan pelayanan yang maksimal bagi masyarakat. Hal tersebut tak lepas bagaimana pemimpin mengatur dan memutuskannya. Seperti halnya di Kelurahan Ketapang Kota Probolinggo, bagaimana pemimpin mengambil keputusan di dalam kondisi pandemik Covid-19.

\section{TINJAUAN PUSTAKA}

\section{Konsep Kepemimpinan}

Berbagai definisi kepemimpinan telah dinyatakan oleh para penulis. Setiap definisi yang dinyatakan oleh para penulis berpijak pada latar belakang dan bidang ilmu yang digeluti. (Kelly-Rawat, S dan Waldock, 2004) menyatakan bahwa pengaruh adalah jantung kepemimpinan. Kepemimpinan tidak dihubungkan dengan posisi atau jabatan tertentu, tetapi dihubungkan dan melekat pada kemampuan seseorang untuk mempengaruhi orang lain. "Kepemimpinan adalah suatu proses untuk mempengaruhi sebuah kelompok yang terorganisir untuk mencapai tujuan-tujuan mereka." Demikian 
Sunarta (2013) memperkuat definisi kepemimpinan yang menggaris bawahi bahwa kepemimpinan adalah pengaruh. Berdasarkan definisi kepemimpinan yang di atas bisa disimpulkan bahwa kepemimpinan harus meliputi beberapa hal penting yaitu: (1) Seni dan ilmu yang dinamis dan bersifat situasional, serta bisa dipelajari; (2) Kemampuan (pengetahuan dan keterampilan) memengaruhi orang lain; (3) keinginan memengaruhi orang lain; (4) kemampuan menggerakkan orang lain berdasarkan cara-cara yang disukai; (5) membantu orang untuk menemukan nilai dan potensi mereka dengan memberikan inspirasi sehingga mereka memiliki keinginan untuk melakukan sesuatu dan menemukannya dalam diri mereka (Kadir, 2018).

Salah satu teori yang mendasarkan diri dengan gaya kepemimpinan adalah teori model kontingensi dari Fiedler. Menurut Fiedler (Gregory Stone et al., 2004) gaya kepemimpinan merupakan cara yang digunakan pemimpin dalam mempengaruhi anak buah, lebih mementingkan tugas (task-oriented) atau lebih mementingkan hubungan (relationship oriented). Adapun faktor-faktor yang mempengaruhi gaya kepemimpinan dikemukakan oleh Schmidt (Gregory Stone et al., 2004) ada 3 yaitu:

a. Latar belakang pengetahuan dan pengalaman seorang pemimpin.

b. Adanya keinginan, kematangan, kemandirian, kebebasan bertindak untuk mendapatkan tanggung jawab serta wewenang bagi para bawahannya.

c. Sifat tugas dan tekanan waktu yang diberikan, serta kenyamanan dari kelompok kerja dalam situasi lingkungan.

Sedangkan menurut Sahertian (2010) terdapat kaitan antara orientasi tugas dan hubungan dalam gaya kepemimpinan, yaitu:

a. Adanya prioritas menyelesaikan tugas dengan maksimal dengan hasil yang baik, namun terjadi hubungan kerja sama yang kurang antara pemimpin dan bawahannya.

b. Sebaliknya, jika memprioritaskan hubungan kerjasama antara pemimpin dan bawahan dengan berdampak baik seperti semangat kerja yang meningkat dan mengabdi terhadap pekerjaan sebagai efek dari suasana kerja yang nyaman. Namun, hal tersebut berdampak pada penyelesaian tugas dan hasil yang berkurang.

Menurut Siagian (1984), efektivitas dan perilaku seorang pemimpin merupakan sebuah keberhasilan bagi organisasinya. Hal tersebut karena timbul dan terpeliharanya semangat kebersamaan. Namun sebaliknya, jika semangat kebersamaan tidak dipelihara dan hanya mementingkan tugas, maka adanya semangat kerja tidak optimal. Hal tersebut jika dilakukan dalam jangka panjang seorang bawahan akan merasa tidak di padang sebagai manusia dan hanya merasa sebagai mesin roda bagi organisasinya (Asnawi, 2015).

Terdapat dua dimensi gaya kepemimpinan yaitu perhatian terhadap tugas (Concern for Task) dan perhatian terhadap karyawan (Concern for People) telah melahirkan teori gaya kepemimpinan yang terkenal dengan The Blake and Mouton Managerial Grid. Sedangkan, menurut Luthas (2002) seorang pemimpin memiliki peran Interpersonal Roles, Informational Roles, Decisional Roles. Sedangkan kegiatan seorang pemimpin Routine Communication, Traditional Management, Networking, dan Human Resource Management. Dan skill seorang pemimpin komunikasi verbal, mengakui, menjelaskan, memecahkan masalah, memotivasi atau mempengaruhi bawahan atau orang lain, dan lain sebagainya yang merupakan sesuatu yang menjadi skill seorang pemimpin (Thoyib, 2005). 


\section{Tipe Kepemimpinan Paternalistik}

Di dalam lingkungan masyarakat agraris ada banyak seorang pemimpin dengan tipe kepemimpinan paternalistik yang masih bersifat tradisional memiliki popularitas yang demikian mungkin disebabkan oleh beberapa faktor sebagai berikut:

a. Kuatnya ikatan primordial,

b. Extended family system,

c. Kehidupan masyarakat yang komunalistik,

d. Peranan adat istiadat yang sangat kuat dalam kehidupan bermasyarakat,

e. Masih di mungkinnya hubungan pribadi yang intim antara seorang anggota masyarakat dan anggota masyarakat lainnya (Buchari, 2019)

Seorang pemimpin dengan tipe kepemimpinan paternalistik memiliki persepsi tentang perannya di dalam kehidupan organisasinya. Perannya tersebut merupakan suatu harapan dari para bawahannya bahwa pemimpin dengan tipe kepemimpinan paternalistik dapat menjadi seorang bapak yang dapat melindungi dan menjadi tempat bertanya untuk memperoleh petunjuk. Beberapa sifat yang diinginkan oleh bawahan terhadap seorang pemimpin dengan tipe kepemimpinan paternalistik yaitu mempunyai sifat tidak mementingkan diri sendiri, agar dapat memberikan kesejahteraan bagi bawahannya. Hal tersebut berakibat pada legitimasi kepemimpinannya, yang dipandang sebagai hal yang wajar dan normal. Seperti, kewenangan dan pengambilan keputusan tanpa harus melibatkan bawahannya. Singkatnya, legitimasi kepemimpinannya berarti penerimaan atas peranannya yang dominan dalam kehidupan organisasional.

Ditinjau dari segi nilai-nilai organisasional yang dianut, biasanya seorang pemimpin dengan tipe kepemimpinan paternalistik mengutamakan kebersamaan. Nilai demikian biasanya terungkap dalam kata-kata, seperti seluruh anggota organisasi adalah anggota satu keluarga besar atau pernyataan-pernyataan lain yang sejenis. Berdasarkan nilai kebersamaan itu, seorang pemimpin dengan tipe kepemimpinan paternalistik bertindak sesuai kepentingan bersama dan perlakuan yang seragam kepada seluruh bawahannya. Sehingga tidak ada orang yang menonjol atau kelompok dominan kecuali pemimpin organisasi tersebut.

Dalam diri seorang pemimpin, beberapa faktor yang telah dikemukakan tersebut diatas tentu terlihat pada gaya keberadaan dan penekanannya, apakah kuat pada kebersamaan. Gaya kepemimpinan seorang pemimpin paternalistik lebih bercorak sebagai pelindung, bapak dan guru. Artinya, dia menekankan kebersamaan bagi para anggota organisasi sedangkan pemimpin yang bersangkutan berada diatas para anggota tersebut (Buchari, 2019).

\section{Pelayanan Publik}

Pelayanan publik adalah suatu bentuk pemberian jasa dengan atau tanpa pembayaran guna memenuhi kebutuhan atau kepentingan masyarakat. Pemberian jasa dalam pelayanan publik, biasanya diberikan oleh pemerintah atau pihak swasta dengan atas nama pemerintah yang sudah saling bekerja sama. Pemberian jasa dalam pelayanan publik sendiri juga bisa diberikan oleh pihak swasta sendiri kepada masyarakat. Maka dengan demikian pelayanan publik diberikan kepada masyarakat oleh instansi pemerintah maupun swasta (Wasistiono, 2003).

Pelayanan publik adalah suatu bentuk kegiatan yang diberikan kepada masyarakat umum atau penduduk negara yang diberikan dalam interaksi langsung maupun tidak langsung dengan tujuan memberikan kemudahan dan kepuasan bagi masyarakat itu sendiri. Pelayanan yang diberikan biasanya berupa barang maupun jasa 
oleh pihak instansi pemerintah baik pusat maupun daerah, atau pihak pemerintah maupun pihak swasta. Tujuan pemberian pelayanan tersebut untuk memenuhi kebutuhan masayarakat maupun dalam rangka pelaksanaan perundang-undangan (Lukman, 1999; Saefullah, 1999).

Sama halnya pelayanan publik menurut Moenir (dalam Kurniawan 2005) adalah suatu kegiatan dengan landasan faktor material melalui sistem, prosedur dan metode tertentu yang dilakukan oleh seseorang atau sekelompok orang dalam usaha memenuhi kepentingan orang lain sesuai dengan haknya. Dalam pengertian tersebut usaha untuk memenuhi kepentingan orang lain sesuai haknya tersebut adalah masyarakat itu sendiri. (Taufiqurokhman \& Satispi, 2018). Dalam Undang - undang Nomor 25 Tahun 2009 tentang Pelayanan Publik adalah serangkaian kegiatan yang disediakan oleh penyelenggara pelayanan publik dalam rangka memenuhi kebutuhan pelayanan sesuai dengan peraturan perundang-undangan bagi setiap warga negara atas barang, jasa, dan/atau pelayanan administratif.

\section{Pandemik Covid-19}

Virus corona telah terjangkit cukup masif di dunia sehingga status virus corona dikatakan sebagai pandemik. Pandemik merupakan suatu istilah yang digunakan ketika suatu wabah atau virus telah menyebar secara global. Itu artinya tidak terbatas pada satu negara saja tapi sudah mendunia. Tanpa terkecuali di Indonesia. Bahkan Indonesia sempat ada di peringkat kedua kematian di dunia akibat corona karena mencapai 8,44\% (CNN Indonesia, 2020). Dalam berita tersebut, sudah 38 orang meninggal dunia akibat corona. Dengan jumlah 38 orang pasien positif corona yang meninggal dunia tersebut, pada saat berita tersebut diluncurkan, maka angka kematian di Indonesia pun berada di angka 8,44\%. Posisi pertama ditempati oleh negara Italia dengan persentase 8,57\%. Urutan ketiga ditempati oleh Spanyol dengan angka kematian 5,06\%.

Berdasarkan kondisi tersebut, maka Indonesia dalam status waspada terhadap ancaman virus corona tersebut. Nyatanya sampai tulisan ini dibuat, pemerintah Indonesia masih menganggap bahwa penanganan virus corona masih sebatas pembatasan sosial saja. Meskipun pembatasan sosial tersebut tidak diuraikan dalam bentuk suatu perundang-undangan, mestinya perlu adanya kriteria dan pelaksanaan pembatasan sosial berskala besar. Banyak kalangan menilai bahwa sudah semestinya tindak lockdown sudah sangat layak diterapkan di Indonesia. Tindak ini dianggap paling efektif untuk mencegah masuknya virus corona dari kedatangan orang dari luar negeri. Tapi pemerintah tidak melakukan tersebut. Justru langkah pembatasan sosial (social distancing). Padahal social distancing ini masih rawan terhadap persebaran virus karena banyak masyarakat yang tidak mau mengikutinya (Arum, 2020).

Dalam surat edaran Walikota Probolinggo Nomor. 800/1630/425.022/2020 perihal pencegahan penyebaran Covid-19 di lingkungan ASN dan Non ASN. Dalam surat edaran tersebut yang merupakan tindak lanjutan dari surat edaran Menteri Dalam Negeri RI tanggal 17 Maret 2020 Nomor: 440/2436/SJ perihal pencegahan penyebaran Covid-19 di lingkungan pemerintah daerah, menyatakan bahwasanya membatasi dan melakukan pengendalian mobilitas ASN/Non ASN di lingkungan kerja masing. Hal tersebut untuk meminimalisir terjadinya penularan atau persebaran virus Covid-19 bagi ASN/Non ASN. 


\section{METODE}

Di dalam penelitian ini, peneliti menggunakan metode kualitatif dan data primer, dimana data diperoleh dari hasil observasi langsung obyek yang diteliti dan dari wawancara dengan pihak terkait, yaitu pihak Kelurahan Ketapang Kota Probolinggo. Oleh karena itu, analisis data menggunakan teknik analisis interaktif yang dikemukakan oleh Miles and Huberman. Analisis interaktif meliputi tahapan pengumpulan data, reduksi data, penyajian data, dan penarikan kesimpulan (Moleong, 2017).

Sesuai dengan judul penelitian ini yaitu Analisis Tipe Kepemimpinan Paternalistik Dalam Peningkatan Pelayanan Publik di Tengah Situasi Pandemik Virus Covid-19, maka penelitian ini menggambarkan kepemimpinan paternalistik yang ada di kelurahan Ketapang Kota Probolinggo dalam masa pandemik virus Covid-19.

\section{HASIL DAN PEMBAHASAN}

Dari hasil penelitian yang dilakukan pada 07 April 2020 dengan 4 narasumber yaitu sekertaris Luran dan 3 staf bagian pelayanan publik di Kelurahan Ketapang Kota Probolinggo. Dalam penelitian ini menjelaskan tipe kepemimpinan paternalistik. Seorang pemimpin dengan tipe kepemimpinan paternalistik memiliki persepsi tentang perannya di dalam kehidupan organisasinya. Perannya tersebut merupakan suatu harapan dari para bawahannya bahwa pemimpin dengan tipe kepemimpinan paternalistik dapat menjadi seorang bapak yang dapat melindungi dan menjadi tempat bertanya untuk memperoleh petunjuk.

Dari hasil wawancara, dapat dibuktikan bahwa Lurah Ketapang merupakan pemimpin dengan tipe kepemimpinan paternalistik. Dari dimensi inspirasional, hasil wawancara dari empat narasumber juga membuktikan bahwa Lurah merupakan sosok pemimpin yang berperan seperti seorang bapak yang sangat mengayomi dan memotivasi para bawahannya dan memberikan dorongan kepada bawahan dalam setiap pekerjaan yang dilakukannya.

Keempat staf Kelurahan Ketapang Kota Probolinggo meyakini bahwa, Lurah yang sekarang sedang memimpin cukup baik dalam menjalankan kewajibannya sebagai Lurah. Narasumber menilai bahwa Lurah sangat cekatan dan cepat dalam pengambilan keputusan. Namun, saat terdapat suatu polemik yang dimana mengharuskan Lurah untuk mengambil suatu keputusan atau kebijakan, Lurah hanya meminta pendapat kepada Camat atau pada sesama Lurah tidak melibatkan pendapat dari para bawahannya. Tidak hanya pada saat terjadi polemik pandemik Covid-19, Lurah dapat langsung memberikan keputusan untuk menyelesaikan masalah yang terjadi di Kelurahan Ketapang, hal tersebut tidak perlu meminta pendapat atau persetujuan dari bawahannya, karena legitimasi kepemimpinannya berarti dalam penerimaan atas peranannya yang dominan dalam kehidupan organisasi.

Dari dimensi konsiderasi individual, hasil wawancara dari keempat narasumber dapat membuktikan bahwa Lurah yang sedang memimpin sekarang ini merupakan seorang pemimpin yang cukup memberikan perhatian dan bantuan kepada para bawahannya.

Dari hasil wawancara dengan narasumber terkait dengan pandemik Covid-19, semua narasumber memberikan pendapat bahwa Covid-19 tersebut sangatlah berbahaya dan bahkan dapat mengancam keselamatan jiwa. Untuk itu, diharapkan bahwa seluruh lapisan masyarakat dapat mengikuti anjuran dan peraturan yang diberikan oleh pemerintah dalam melakukan pencegahan penularan Covid-19 ini. Anjuran yang diberikan oleh pemerintah dalam bentuk himbauan tersebut misalnya setiap masyarakat disarankan untuk menggunakan masker, menjaga jarak dengan individu yang lain minimal 1.5 meter 
(social distancing), sering mencuci tangan atau menggunakan hand sanitizer dan melakukan penyemprotan di seluruh wilayah. Pihak kelurahan Ketapang sendiri juga menerapkan himbauan dari pemerintah terutama dalam hal pelayanan publik. dengan adanya pandemik Covid-19 tidak membuat pelayanan publik diberhentikan. Pelayanan publik tetap berjalan baik secara langsung maupun secara online. Namun, dalam upaya pencegahan penularan Covid-19, pihak kelurahan Ketapang juga menerapkan peraturan dari pemerintah yaitu pengurangan jam kerja yang dimana biasanya dari pukul $08.00 \mathrm{~s} / \mathrm{d}$ 16.00 WIB sekarang dirubah menjadi pukul $08.00 \mathrm{~s} / \mathrm{d} 13.00$ WIB. Pihak kelurahan juga meniadakan kursi pelayanan yang biasanya dapat diduduki oleh warga yang sedang melakukan pengurusan data di kelurahan Ketapang. Hal tersebut juga merupakan upaya pencegahan Covid-19 dimana dalam proses pelayanan warga dapat menjaga jarak dengan para staf yang melayani mereka. Pemerintah juga melarang masing-masing pegawai untuk berjabat tangan baik itu antara pegawai dengan sesama pegawai ataupun antara pegawai dengan warga masyarakat.

sama halnya dengan pelayanan publik yang dilakukan oleh KBRI Korea Selatan ataupun pemerintah Korea Selatan. Pelayanan publik yang dilakukan oleh KBRI Korea Selatan dalam pelayanan kekonsuleran, keimigrasian, konsultasi ketenagakerjaan dan kesehatan dilaksanakan di hari Minggu (10/05/2020), pemberian pelayanan publik tersebut tetap mematuhi kebijakan dan protokol kesehatan yang berlaku di Korea Selatan. Untuk memastikan WNI mendapat pelayanan yang optimal dan cepat, KBRI Korea Selatan menerapkan pendaftaran daring atau online. Hal tersebut dilakukan agar jumlah orang yang datang terkontrol dengan waktu pelayanan yang pasti. Sehingga mengurangi resiko berkumpulnya orang banyak dalam waktu bersamaan. Berkat inovasi ini, lama waktu pelayanan jadi lebih singkat, tidak sampai sepuluh menit per orang. Sedangkan pelayanan publik yang diberikan saat hari kerja dilaksanakan dengan pengaturan jumlah pengunjung, hal tersebut dilakukan untuk memastikan keselamatan, keamanan dan kenyamanan bersama. KBRI Korea Selatan memahami pengaturan jumlah tersebut perlu diikuti dengan pelayanan di hari libur agar bisa menjangkau WNI lebih banyak lagi. KBRI Korea Selatan akan terus memantau kebutuhan pelayanan publik bagi para WNI agar bisa tetap aktif dengan lebih sehat dan aman saat beraktivitas di tengah pandemik COVID-19.

Sama halnya dengan pelayanan publik di Korea Selatan sendiri terbilang sangat efektif dalam menekan laju persebaran Covid-19. Upaya yang dilakukan oleh Korea Selatan yaitu dengan menyederhanakan birokrasi dari tingkat pusat sampai dengan tingkat daerah, sehingga dampaknya adalah pemerintahan menjadi solid. Sehingga, kebijakan yang dibuat oleh pemerintah pusat dapat turun dan dijalankan dengan cepat oleh pemerintah daerah. Begitupun dengan pelayanan, pelayanan yang diberikan dapat dirasakan dengan cepat, responsif, dan memuaskan selama masa pandemik menjadikan masyarakat Korea Selatan puas terhadap pemerintahannya. Selain itu, penyederhanaan birokrasi dapat mempercepat pelayanan kepada masyarakat. Sedangkan kebijakan tidak dibahas secara lama dan berjenjang panjang dengan cara disposisi, namun kebijakan dapat diputuskan dengan cepat dan tepat dalam rangka memberikan pelayanan yang responsif sekaligus memuaskan kepada masyarakat (Wibowo, 2020). Hal tersebut mirip seperti tipe kepemimpinan paternalistik yang mana kewenangan dan pengambilan keputusan tanpa harus melibatkan bawahannya. Singkatnya, legitimasi kepemimpinannya berarti penerimaan atas peranannya yang dominan dalam kehidupan organisasional.

\section{KESIMPULAN}

Berdasarkan hasil analisis yang dipaparkan dalam hasil penelitian dan pembahasan, dapat disimpulkan bahwa Bapak Zainul Faruq merupakan seorang pemimpin dengan tipe 
kepemimpinan paternalistik dimana beliau sangat mengayomi dan perhatian terhadap para bawahannya layaknya seorang bapak dalam sebuah organisasi di Kelurahan Ketapang Kota Probolinggo. Para bawahannya menilai bahwa sebagai seorang pemimpin, beliau sudah menjalankan kewajibannya dengan cukup baik karena beliau begitu cekatan dan cepat dalam pengambilan keputusan. Dalam menangani setiap polemik yang terdapat dalam lingkungan masyarakat, Lurah juga ikut serta dalam menanganinya, namun bukan untuk menghakimi. Termasuk mengenai pandemi covid-19, Lurah juga sangat bijak dimana menganjurkan kepada para bawahannya untuk mengikuti peraturan yang diberikan oleh pemerintah dalam upaya pencegahan penularan covid-19 tersebut. Dalam layanan publik beliau tetap mengadakan proses pelayanan publik, namun pelayanan publik yang diberikan terdapat beberapa tambahan peraturan seperti meniadakan kursi bagi masyarakat di dalam ruangan pelayanan, dan memberikan tempat cuci tangan hal tersebut untuk mencegah penularan atau penyebaran Virus Covid-19 sendiri. Para bawahan berharap bahwa pada periode kepemimpinan yang berikutnya tetap Lurah yang menjabat sebagai Lurah Ketapang, hal tersebut karena beliau mampu berperan sebagai bapak yang bersifat melindungi dan layak dijadikan tempat bertanya dan memperoleh petunjuk.

\section{DAFTAR RUJUKAN}

Arum, R. (2020). PEMBATASAN SOSIAL DI INDONESIA AKIBAT VIRUS CORONA DITINJAU DARI SUDUT PANDANG POLITIK. Politic Solitic.

Asnawi, S. (2015). Semangat kerja dan gaya kepemimpinan. Jurnal Psikologi, 2, 86-92.

Asy'ari, H., Syaripullah, \& Prasetyo, G. P. (2013). PERAN KEPEMIMPINAN KEPALA DESA KANEKES(JARO PAMARENTAH) TERHADAP PENDIDIKANMASYARAKAT BADUY LUAR. HIJRI - Jurnal Manajemen Pendidikan Dan Keislaman, 53(9), 1689-1699. https://doi.org/10.1017/CB09781107415324.004

Buchari, A. dan S. M. (2019). Kepemimpinan dan Kekuasaan: Antara Ide Dan Kenyataan. Trim Komunikata.

Daswati. (2012). Implementasi peran kepemimpinan dengan gaya kepemimpinan menuju kesuksesan organisasi. Academica Fisip Untad, 04(01), 783-798. http://jurnal.untad.ac.id/jurnal/index.php/academica/article/view/2272

Erlangga, F., Frinaldi, A., \& Magriasti, L. (2014). Pengaruh Gaya Kepemimpinan Paternalistik Terhadap Motivasi Kerja Pegawai Dinas Sosial Dan Tenaga Kerja Kota Padang. Humanus, 12(2), 174. https://doi.org/10.24036/jh.v12i2.4037

Everett, J. A., Colombatto, C., Chituc, V., Brady, W. J., \& Crockett, M. J. (2020). The effectiveness of moral messages on public health behavioral intentions during the COVID-19 pandemic. PsyArXiv, 1-23. https://doi.org/10.31234/osf.io/9yqs8

Gregory Stone, A., Russell, R. F., \& Patterson, K. (2004). Transformational versus servant leadership: A difference in leader focus. Leadership \& Organization Development Journal. https://doi.org/10.1108/01437730410538671

Hadiyanti, H. (2015). PERAN KEPEMIMPINAN CAMAT DALAM MENINGKATKAN KINERJA APARATUR BIROKRASI DI KECAMATAN SAMBOJA KABUPATEN KUTAI KARTANEGARA. EJournal Administrasi Negara, 3(1), 206-219.

Kadir, I. A. (2018). ANALISIS GAYA KEPEMIMPINAN WALIKOTA PADA SEKRETARIAT DAERAH (SEKDA) KOTA TIDORE KEPULAUAN. Ecosystem, 16, 1-26.

Kelly-Rawat, S dan Waldock, T. (2004). The 18 Challenges of Leadership: A Practical, Structured Way to Develop Your Leadership Talent. Prentice Hall.

Lukman, S. (1999). Manajemen KualitasPelayanan. STIA LAN Press.

Moleong, L. J. (2017). Metodologi Penelitian Kualitatif (Edisi Revisi). PT. Remaja Rosdakarya. Saefullah. (1999). Konsep dan Metode Pelayanan Umum yang Baik, dalam Jurnal Ilmu Sosial 
dan Ilmu Politik. Fisip UNPAD.

Sahertian, P. (2010). Perilaku Kepemimpinan Berorientasi Hubungan Dan Tugas Sebagai Anteseden Komitmen Organisasional, Self-Efficacy Dan Organizational Citizenship Behavior (OCB). Jurnal Manajemen Dan Wirausaha, 12(2), 156-169. https://doi.org/10.9744/jmk.12.2.pp.156-169

Sunarta. (2013). Memilih Pemimpin Dalam Praktik Kepemimpinan Organisasi Sekolah di Era Global. Jurnal Informasi, 39(2), 69-82. https://doi.org/10.21831/informasi.v0i2.4445

Taufiqurokhman, \& Satispi, E. (2018). Teori Dan Perkembangan Manajemen Pelayanan Publik. UMJ PRESS 2018, 266.

Thoyib, A. (2005). Hubungan Kepemimpinan, Budaya, Strategi, Dan Kinerja: Pendekatan Konsep. Jurnal Manajemen Dan Wirausaha, 7(1), 60-73. https://doi.org/10.9744/jmk.7.1.pp.60-73

Tim. (2020). Mengenal Makna Status Pandemi Virus Corona. CNN Indonesia. https://www.cnnindonesia.com/gaya-hidup/20200312113105-255482774/mengenal-makna-status-pandemi-virus-corona

Wasistiono, S. (2003). Manajemen Pemerintahan Daerah. CV. Fokusmedia.

Wibowo, P. (2020). Birokrasi selama Masa Pandemi. Komisi Aparatur Sipil Negara. https://www.kasn.go.id/details/item/570-birokrasi-selama-masa-pandemi 